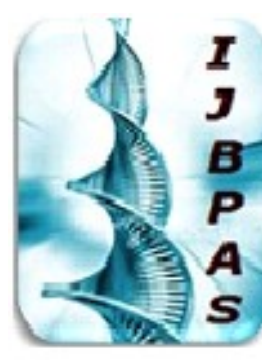

International Journal of Biology, Pharmacy and Allied Seiences (IJBPAS)

'A Bridge Betueen Caboratory and QRendo'

Www.iibpas.com

\title{
DEVELOPMENT AND EVALUATION OF ANTI-INFLMMATORY GEL FROM AMORPHOPHALLUS PAEONIIFOLIUS
}

\section{MODAK N ${ }^{*}{ }^{1}$, THAKARE $\mathbf{V}^{1}$, SURESH E ${ }^{1}$ AND JEEVAN DHUMAL ${ }^{2}$}

1: Department of Pharmaceutical Quality Assurance, Dadasaheb Balpande College of Pharmacy,

$$
\text { Nagpur, (440037) India }
$$

2: Rajmata Jijau Shikshan Prasarak Mandal's College of Pharmacy, Dudulgaon (412105), Pune, Maharashtra, India

*Corresponding Author: Dr. V. M. Thakare; E Mail: vmthakre@gmail.com

Received $25^{\text {th }}$ April 2021; Revised $24^{\text {th }}$ June 2021; Accepted $30^{\text {th }}$ July 2021; Available online $1^{\text {st }}$ Oct. 2021 https://doi.org/10.31032/IJBPAS/2021/10.10.1029

\begin{abstract}
Objectives: Validate the study of phytoconstituents from the extracts of Amorphophallus paeoniifolius tubers for the Anti-Inflammatory activity and prepare the extract into gel form and evaluate the gel formulation for anti-inflammatory study. Methodology: Amorphophallus paeoniifolius tuber extract which was successively extracted in various non-polar to polar solvents. Performed preliminary phytochemical tests for Amorphophallus paeoniifolius tuber extract. The extract was evaluated for Flavonoid content, phenolic content and antioxidant activity. HRBC study for Anti- Inflammatory activity for various extract was performed. TLC \& comparative TLC for methanolic extract was carried out. Comparative microbial test of Amorphophallus paeoniifolius tuber extract with marketed formulation on S.aureus stains. Formulations were prepared and evaluated on different parameters. Results: Amorphophallus paeoniifolius tuber extract showed the maximum presence of secondary metabolites in methanolic extract. The total flavonoid content were found to be $11.13 \pm 0.118$ and $14.83 \pm 0.455 \mathrm{mg}$ of QE/g in methanol extract and total phenolic content was found to be $8.54 \pm 0.043$ and $10.26 \pm 1.66 \mathrm{mg}$ of GA/g in methanol extract and Amorphophallus paeoniifolius tuber extract showed significant antioxidant activity in methanolic extract. Methanolic extract showed the maximum anti-inflammatory activity for HRBC. The comparative microbial study with marketed formulation shows good results and thus herbal formulation of Amorphophallus paeoniifolius tuber may be used to cure Inflammation. Conclusion: From this study, we concluded that Amorphophallus paeoniifolius tuber may be used for the inflammation.
\end{abstract}

Keywords: anti-inflammatory, Amorphophallus paeoniifolius, methanolic extract, microbial, HRBC 


\section{INTRODUCTION}

Inflammation is a tissue's and its microcirculation's response to a pathogenic outcome. The production of inflammatory mediators, as well as the migration of fluid and leukocytes from the bloodstream into extravascular tissues, characterise this condition [1].

The inflammation response's main goal is to remove pathogenic insults and injured tissue components. This procedure either results in the restoration of normal tissue architecture and physiological function, or in the formation of scar tissue to replace what cannot be repaired ${ }^{7}$. Inflammation, however, appears to cause more harm than good in certain circumstances. The cartilage can be destroyed by neutrophil lysosomal enzymes that reach the area when inflammation affects a joint (rheumatoid arthritis, for example). Another example is that tumours appear to form in areas that are chronically irritated. As a result, we refer to inflammation as a two-edged sword [2].

Inflammation has traditionally been classified as acute or chronic, depending on the duration of the damage, clinical symptoms, and the type of the inflammatory response [1]. Accumulation of fluid and plasma components in the injured tissue, intravascular activation of platelets [2], and the presence of polymorphonuclear leukocytes are all signs of acute inflammation. Lymphocytes, plasma cells, and macrophages are all characteristics of chronic inflammation [3].

\section{Pathophysiology of Inflammation}

Regardless matter the aetiology, the inflammatory response is very similar. Inflammation can be caused by a variety of factors. Inflammation can be caused by a variety of factors, including infection (the presence of living bacteria within the tissue). Inflammation can easily occur even in the most sterile situations, such as when a section of tissue dies due to a lack of blood flow [2].

Acute inflammation is the body's rapid and early response to injury, with the goal of delivering leukocytes to the injury site. Leukocytes arrive and eliminate any invading bacteria before starting to break down necrotic tissues.

There are two essential components to this procedure:

1) Vascular changes: changes in vessel diameter that result in increased blood flow (vasodilation) and structural changes that allow plasma protein to exit circulation (increased vascular permeability).

2) cellular events: leukocyte emigration from the microcirculation and accumulation in the injured site (cellular recruitment and activation) [4]

Viral infection, persistent microbial infections, prolonged exposure to 
potentially harmful chemicals, and autoimmune illnesses are all examples of chronic inflammation. Chronic inflammation is defined as inflammation that lasts for a long time (weeks, months, or years) and is characterised by active inflammation, tissue injury, and healing all occurring at the same time [4]. Aside from inflammation with mononuclear (chronic inflammatory) cells, tissue death, which is predominantly controlled by inflammatory cells, and repair, which involves new vessel growth (angiogenesis) and fibrosis, are also involved [4].

Elephant foot yam (Amorphophallus paeoniifolius) is a tropical tuber crop of the Araceae family with a lot of promise. Because of its high output potential and culinary qualities, it is a major tuber crop in tropical and subtropical nations. These tuber have a good anti-inflammatory activity and it is used to treat arthritis, elephantiasis, glandular swelling and others. This plant's tuber has a great therapeutic value and is eaten as a meal. It's linked to acridity (an itching sensation in the mouth and throat) and the presence of elevated oxalates raphides [1]. It also contains a lot of vitamin B-6, which helps ladies with premenstrual syndrome. It's a natural product with a lot of fibre. It has a high concentration of vital minerals and can be used as a slimming food because it lowers cholesterol and helps weight loss.
People who have traditionally relied on starch-rich diets may be unaware of the nutritional value of new high-yielding elephant foot yam types [6].

\section{MATERIALS AND METHODS}

\section{The various material and methods used} in research are given below Amorphophallus paeoniifolius tuber from local market, Chandrapur, Petroleum ether, Ethyl acetate, Ethanol, Methanol, Folin ciocalteu reagent obtained from LOBA chemie, Mumbai. India, Gallic acid from SunCHEM and DPPH from Sisco research laboratory Mumbai. India.

\section{COLLECTION AND AUTHENTICATION:}

Dried Amorphophallus paeoniifolius tuber were collected from local market of Chandrapur region, Maharashtra and authenticated from botanical department RTM Nagpur University India.

\section{PREPARATION OF EXTRACT: [7]}

The continuous hot extraction process was used for the extraction. Amorphophallus paoniifolius tubers were cleaned and dried. Approximately $50 \mathrm{gm}$ of Amorphophallus paoniifolius tubers were taken into a thimble and placed in a soxhlet apparatus. It was extracted successively by using solvents petroleum ether, chloroform, ethanol, methanol and macerated by hydroalcholic solvents (Methanol: water) and lastly with water

PRELIMINARY PHYTOCHEMICAL SCREENING: [8] 
The methods used for detection of various phytochemicals were followed by qualitative chemical test to give general idea regarding the nature of constituents present in crude drug. The qualitative chemical tests for various phytoconstituents were carried out for all the extracts of Amorphophallus paeoniifolius tuber.

\section{TLC FINGERPRINTING: [9]}

Thin layer chromatography (TLC) is a chromatography technique used to separate mixtures. To conform the secondary metabolite in the extracts by using silica gel-G as a stationary phase for separation of phytochemical compounds. Extract were spotted to prepared plate manually by using capillary and put into suitable mobile phase. Because of different analytes ascend the TLC plate at different rates, separation is achieved. The petroleum ether and methanol extracts of the Amorphophallus paeoniifolius were subjected to thin layer chromatographic analysis, to find the presence of number of chemical constituents to support the chemical test.

\section{DETERMINATION OF TOTAL PHENOLIC CONTENT: [10]}

Total phenol content of methanolic extracts of Amorphophallus paeoniifolius tuber was determined by using modified FolinCiocalteau method. Absorbance of the test sample was measured at $\lambda \max =765 \mathrm{~nm}$. Total phenolic content was expressed as (mg of GAE/g of gallic acid) equivalent using the following linear regression equation based on the calibration curve: (r2 $=0.9989), \mathrm{y}=0.0056 \mathrm{x}+0.0103$, where $\mathrm{x}$ stand for absorbance and y stand for gallic acid equivalent $(\mathrm{mg} / \mathrm{g})$.

\section{DETERMINATION OF TOTAL FLAVONOIDS CONTENT: [11]}

The total flavonoid content of methanolic extract of Amorphophallus paeoniifolius tuber was determined by the aluminium chloride colorimetric method. Absorbance was measured at $510 \mathrm{~nm}$ and yellow colour indicated the presence of flavonoids. Total flavonoid content was calculated as quercetin (mg of QE/g) using the following equation based on the calibration curve: (r2 $=0.992), \mathrm{y}=0.0065 \mathrm{x}+0.0337$ where $\mathrm{x}$ stand for absorbance and $y$ stand for quercetin equivalent $(\mathrm{mg} / \mathrm{g})$.

\section{ANTIOXIDANT ACTIVITY (DPPH RADICAL SCAVENGING ASSAY): [12]}

The total flavonoid content of methanolic extract of Amorphophallus paeoniifolius tuber was determined by the aluminium chloride colorimetric method. Absorbance was measured at $510 \mathrm{~nm}$ and yellow colour indicated the presence of flavonoids. Total flavonoid content was calculated as quercetin (mg of QE/g) using the following equation based on the calibration curve: (r2 $=0.992), \mathrm{y}=0.0065 \mathrm{x}+0.0337$ where $\mathrm{x}$ stand for absorbance and $y$ stand for quercetin equivalent $(\mathrm{mg} / \mathrm{g})$. 


\section{IN-VITRO ANTI-INFLAMMATORY} ACTIVITY: [13]

In-vitro anti-inflammatory activity of extracts of B. ceiba was assessed by Human Red Blood Corpuscles (HRBC) membrane stabilizing method with slight modifications. The blood was collected from healthy human volunteer who had not taken any antiinflammatory drugs for 2 weeks prior to the experiment and transferred to the heparinized centrifuge tubes and centrifuged at $3,000 \mathrm{rpm}$. The packed cells were washed with isosaline and a $10 \%$ suspension in normal saline was made. Diclofenac potassium $(50 \mu \mathrm{g} / \mathrm{ml})$ was used as standard. The reaction mixture (4-5 $\mathrm{ml}$ ) consisted $2 \mathrm{ml}$ of hypotonic saline $(0.25 \% \quad \mathrm{w} / \mathrm{v} \mathrm{NaCl}), 1 \mathrm{ml}$ of $0.15 \mathrm{M}$ phosphate buffer ( $\mathrm{pH} 7.4$ ), and $1 \mathrm{ml}$ of test solution $(1000 \mu \mathrm{g} / \mathrm{ml})$ in normal saline and $0.5 \mathrm{ml}$ of $10 \% \mathrm{HRBC}$ in normal saline. For control, $1 \mathrm{ml}$ of isotonic saline was used instead of test solution. The mixtures were incubated at $56^{\circ} \mathrm{Cfor} 30 \mathrm{~min}$. and cooled at running tap water, centrifuge at $3000 \mathrm{rpm}$ for $20 \mathrm{~min}$. The absorbance of supernatant was read at $560 \mathrm{~nm}$ using visible Spectrophotometer. The experiment was performed in triplicates. The Percentage membrane stabilization was calculated using the following formula:

\begin{tabular}{|c|}
\hline$\%$ Inhibition of Haemolysis- [Absorbance of control - Absorbance of test] $\quad \times 100$ \\
\hline
\end{tabular}

\section{FORMULATION OF GEL: [14]}

Required quantity of polymer (carbapol971) was weighed individually, and sufficient amount of distilled water were mixed in a separate beaker, after which it was continuously stirred by mechanical stirrer till the polymer is soaked in the water and kept for $24 \mathrm{~h}$ at room temperature. With continuous stirring, now the appropriate quantity of methyl paraben and propyl paraben was added which acts as a preservative. Small quantities of triethanolamine were added with continuous stirring to achieve neutral $\mathrm{pH}$. Finally extract was added to gel with continuous stirring till drug get dispersed completely. The prepared gel was filled and sealed in the aluminium collapsible tube. A similar procedure was followed for base control gel without the extract.

\section{EVALUATION OF GEL FORMUL- ATIONS: [15-17]}

Prepared formulations were evaluated for various physicochemical parameters such as colour, homogeneity, $\mathrm{pH}$, spreadability, viscosity and drug content (total flavanoid content).

\section{ACCELERATED STABILITY STUDY:}

[14]

Stability studies for this present work was carried out at $40^{\circ} \mathrm{C} \pm 2{ }^{\circ} \mathrm{C} 75 \% \mathrm{RH}$ for the selected formulation for three months. The 
selected formulations were packed in amber bottle. They were stored at $40^{\circ} \mathrm{C} \pm 2^{\circ} \mathrm{C} / 75 \pm 5 \% \mathrm{RH}$ for 3 months in humidity chamber and evaluated for their physical appearance and various parameters at specified intervals of time.

COMPARATIVE MICROBIAL ASSAY: [18]

Agar well diffusion method: This method is commonly used to check the antimicrobial activity of plants or microbial extracts. Similarly to the procedure utilized in disk diffusion method, the agar plate surface is inoculated by spreading a volume of the microbial inoculum over all agar surfaces. Then, a hole with measurement across object of 6 to $8 \mathrm{~mm}$ is punched aseptically with a sterile plug borer or a tip and a volume of standard drug (diclofenac60mg/ml), methanolic extract of $(10 \mathrm{mg} / \mathrm{ml})$ and formulation optimize batch G7 $(1 \% \mathrm{w} / \mathrm{v})$ introduced in to the wall. Then agar plates are incubated for $24 \mathrm{hr}$, under applicable conditions depending upon the microorganisms.

\section{RESULTS AND DISCUSSION}

Authentication of Plant: The plant was authenticated from Botany Department of RTMNU and having the authentication Voucher specimen no. is 10450.

The Preliminary phytochemical constituents are showed in Table 1.

THIN LAYER CHROMATOGRAPHY:
Assessment of secondary metabolites were observed by TLC and was confirmed by comparative TLC and the Rf value was match with standard and showed in Table 2.

\section{TOTAL PHENOLIC CONTENT:}

The phenolic content was calculated using the linear regression equation obtained from standard gallic acid graph $(\mathrm{r} 2=$ 0.9989), $\mathrm{y}=0.0056 \mathrm{x}+0.0103$. Among test extracts at concentrations $50 \mu \mathrm{g} / \mathrm{ml}$ and $100 \mu \mathrm{g} / \mathrm{ml}$, the total phenolic content was found to be $15.9 \pm 0.613$ and $12.5 \pm 0.412$ $\mathrm{mg}$ of $\mathrm{GA} / \mathrm{g}$ in methanol extract of Amorphophallus paeoniifolius tuber.

\section{TOTAL FLAVONOID CONTENT:}

Flavonoid content was calculated using the linear regression equation obtained from standard quercetin graph $(\mathrm{r} 2=0.992), \mathrm{y}=$ $0.0065 x+0.0337$. Among test extracts at concentrations $50 \mu \mathrm{g} / \mathrm{ml}$ and $100 \mu \mathrm{g} / \mathrm{ml}$, the total flavonoid content were found to $7.47 \pm$ 0.042 and $9.58 \pm 0.056 \mathrm{mg}$ of $\mathrm{QE} / \mathrm{g}$ in methanol extract of Amorphophallus paeoniifolius tuber.

\section{ANTIOXIDANT ACTIVITY STUDY:}

Evaluation of scavenging activity on DPPH radicals:

\% scavenging of DPPH $=($ Acontrol - Atest $) /$

$$
\text { Acontrol } \times \mathbf{1 0 0}
$$

The methanolic extract of Amorphophallus paeoniifolius tuber showed significant antioxidant activity as compared with the ascorbic acid Shows in Table 3. The antioxidant activity of scavenging activity 
on DPPH radicals may due to the presence of flavonoids, tannins and phenol.

\section{DETERMINATION OF ANTI-INFLAMM- ATORY ACTIVITY (HRBC)}

The Table 4 showed the HRBC parameters and its $\%$ inhibition by the extract was showed.

\section{EVALUATION OF GEL}

The gel formulations of methanolic extract of Amorphophallus paeoniifolius batch F7 shows satisfactory result in parameters such as colour and appearance, $\mathrm{pH}$, viscosity, extrudability, spreadability, drug content.
Therefore, formulation F7was selected for post stability evaluation and that data was showed in Table 5.

\section{COMPARATIVE MICROBIAL ASSAY:}

The comparative microbial assay showed that extract may have antimicrobial activity which was showed in Table 6.

\section{ACCELERATED STABILITY STUDY:}

The accelerated stability was performed for 3 months due to time constraint. Study's parameter and results were showed in Table 7 for Colour and appearance, $\mathrm{pH}$ Viscosity, \% Drug remaining.

Table 1: Preliminary phytochemical screening

\begin{tabular}{|c|c|c|c|c|c|c|}
\hline Sr. No. & constituents & PEE & CE & EE & ME & HAE \\
\hline 1. & Sterols & + & - & + & - \\
\hline 2. & Alkaloids & - & + & - & + \\
\hline 3. & flavonoids & - & - & + & + \\
\hline 5. & Proteins & - & - & - & - \\
\hline 7. & Glycosides & - & - & - & + \\
\hline
\end{tabular}

PEE-Petroleum ether extract, CE-Chloroform extract, EE-ethanol extract, ME- methanol extract, HAEhydroalcholic extract; + Presence, - Absence

Table 2: TLC and comparative TLC of extract






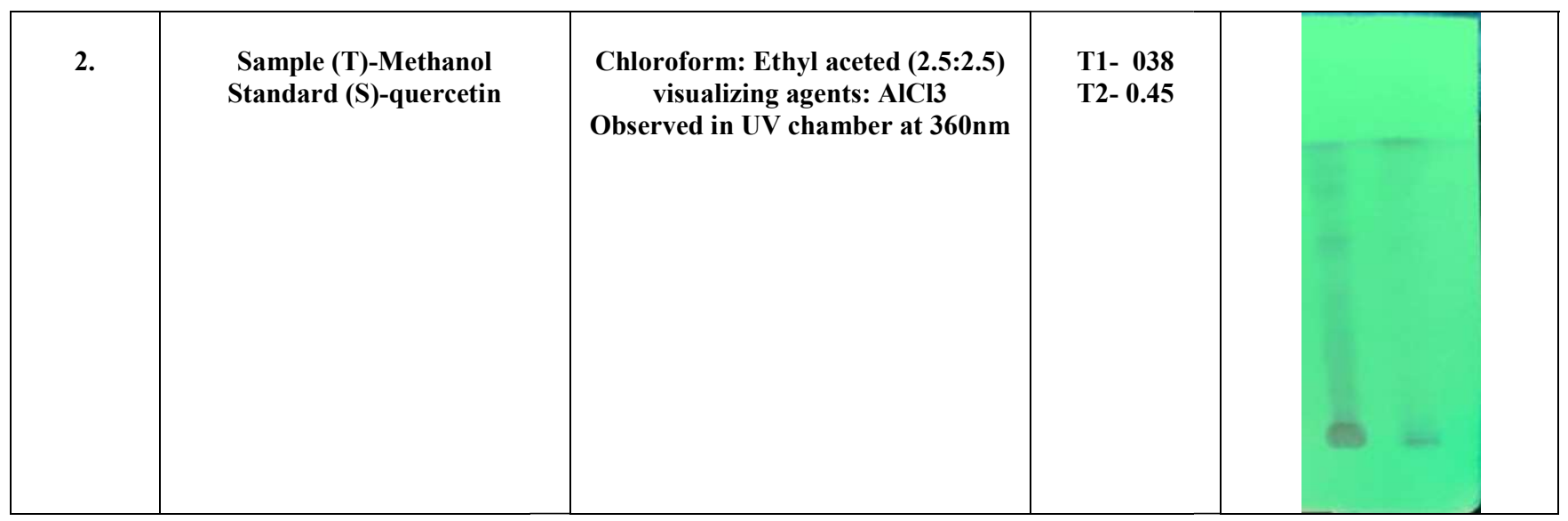

Table No 3: Effects of test extracts on \% DPPH inhibition

\begin{tabular}{|c|c|c|}
\hline \multirow{2}{*}{$\begin{array}{c}\text { Conc. } \\
(\mu \mathrm{g} / \mathrm{ml})\end{array}$} & \multicolumn{2}{|c|}{ \% scavenging activity on DPPH radicals } \\
\cline { 2 - 3 } & Ascorbic acid & ME \\
\hline 25 & $\mathbf{3 3 . 1 2} \pm \mathbf{0 . 6 2}$ & $\mathbf{1 8 . 8 7} \pm 0.81$ \\
\hline $\mathbf{5 0}$ & $\mathbf{4 5 . 3 8} \pm 0.65$ & $\mathbf{2 9 . 1 2} \pm 0.72$ \\
\hline 75 & $\mathbf{6 9 . 9 8} \pm 0.68$ & $38.31 \pm 0.59$ \\
\hline 100 & $\mathbf{8 1 . 6 6} \pm 1.02$ & $45.39 \pm 0.68$ \\
\hline 125 & $\mathbf{9 8 . 2 7} \pm 0.63$ & $\mathbf{5 6 . 2 1} \pm 1.02$ \\
\hline
\end{tabular}

Values expressed as Mean $\pm \mathrm{SD}, \mathrm{n}=3$

Table 4 Anti-inflammatory activity of various Extract

\begin{tabular}{|c|c|c|}
\hline Parameters & Absorbance & \% inhibition \\
\hline Control & $\mathbf{0 . 4 6 0}$ & - \\
\hline Petroleum extract & $\mathbf{0 . 3 5 8}$ & $\mathbf{2 2 . 3 6}$ \\
\hline Methanol extract & $\mathbf{0 . 3 3 5}$ & $\mathbf{2 7 . 1 7}$ \\
\hline Ethanol extract & $\mathbf{0 . 3 8 5}$ & $\mathbf{1 6 . 3 0}$ \\
\hline Diclofenc & $\mathbf{0 . 1 9 6}$ & $\mathbf{5 7 . 3 9}$ \\
\hline
\end{tabular}

Table 5: Colour and appearance, $\mathrm{pH}$, viscosity, Extrudability, Spreadability, Drug content (phenolic content)

\begin{tabular}{|c|c|c|c|c|c|c|}
\hline Formulations & $\begin{array}{l}\text { Colour and } \\
\text { appearance }\end{array}$ & pH & $\begin{array}{c}\text { Viscosity } \\
\text { cps }\end{array}$ & Extrudability & Spredability & $\begin{array}{c}\text { Drug content } \\
\%\end{array}$ \\
\hline G1 & Light brown & 6.4 & 614100 & $81.25 \pm 5.6$ & 13.11 & 24.14 \\
\hline G2 & Light brown & 6.5 & 672000 & $83.27 \pm 5.3$ & 13.32 & 25.64 \\
\hline G3 & Light brown & 6.8 & 674000 & $93.88 \pm 3.1$ & 17.20 & 31.87 \\
\hline G4 & Light brown & 7.1 & 685000 & $90.11 \pm 4.6$ & 19.21 & 39.24 \\
\hline G5 & Light brown & 6.6 & 697000 & $95.56 \pm 4.3$ & 21.48 & 47.54 \\
\hline G6 & Light brown & 6.9 & 753000 & $87.98 \pm 2.5$ & 22.24 & 55.60 \\
\hline G7 & Light brown & 7 & 784000 & $97.45 \pm 4.1$ & 25.14 & 55.90 \\
\hline G8 & Light brown & 7.1 & 788000 & $87.26 \pm 5.4$ & 25.10 & 57.15 \\
\hline G9 & Light brown & 6.5 & 791000 & $98.13 \pm 2.6$ & 23.24 & 57.89 \\
\hline
\end{tabular}

Table 6: Comparative microbial assay in $S$. aureus cultures

\begin{tabular}{|l|c|c|c|c|}
\hline Culture & \multicolumn{4}{|c|}{ Samples } \\
\hline \multirow{2}{*}{ S.aureus } & Zone of inhibition & Standard & Methanolic extract & Formulation \\
\cline { 2 - 5 } & & $3 \mathrm{~cm}$ & $3.2 \mathrm{~cm}$ & $2.8 \mathrm{~cm}$ \\
\hline
\end{tabular}




Table 7: Accelerated stability study of optimise batch F7

\begin{tabular}{|c|c|c|c|c|}
\hline \multirow{2}{*}{ Parameter } & \multicolumn{4}{|c|}{ Storage (in month) } \\
\cline { 2 - 5 } & Initial & st month & 2 month & 3 rd \\
& Light brown & Light brown & Light brown & Light brown \\
\hline Colour and appearance & 7 & 7.1 & 6.9 & 7.1 \\
\hline pH & $\mathbf{7 8 4 0 0 0}$ & $\mathbf{7 7 9 0 0}$ & $\mathbf{7 8 5 0 0}$ & 771000 \\
\hline Viscosity & $\mathbf{5 5 . 9 0}$ & $\mathbf{5 5 . 6 5}$ & $\mathbf{5 5 . 9 0}$ & $\mathbf{5 5 . 9 1}$ \\
\hline
\end{tabular}

\section{SUMMARY}

The main objectives of these study were to formulate evaluate the anti-inflammatory activity of Amorphophallus paeoniifolius tuber extract. The successive extraction was carried out in various solvents (non-polar to polar solvents). The yield was calculated in percentage $\%$. The $\%$ yield of Petroleum Ether extract was found $1.05 \%$, Chloroform extract was found $1.8 \%$, Ethanol extract was found 4\%, Methanol extract was found $3.5 \%$, Hydro-alcoholic extract was found $4.5 \%$. The preliminary phytochemical screening showed various secondary metabolites. TLC fingerprinting showed the presence of various secondary metabolites in Amorphophallus paeoniifolius tuber extract. Methanolic extract showed presence of phenol content was found to be $15.9 \pm 0.613$ and $12.5 \pm 0.412 \mathrm{mg}$ of $\mathrm{GA} / \mathrm{g}$ and flavonoid content was found to be $7.47 \pm 0.042$ and $9.58 \pm 0.056$ of QE/g. The flavonoid and phenolic content was found in satisfactory range when it's compared with previous research paper which I have referred for this study.

The anti-oxidant study shows that scavenging activity on DPPH radicals was found to be higher inhibition of DDPH was exhibited by methanol extract $56.21 \pm 1.02$ was compared to ascorbic acid. From the HRBC study the maximum Antiinflammatory activity showed in methanolic extract and it was found to be $57.39 \%$.

The gel formulation from Amorphophallus paeoniifolius tuber extract were showed in good result in various parameter. And the various evaluation parameter was carried out for 9 batches (G1-G9). Among the 9 batches, G7 batch showed the good result and there colour and appearance, $\mathrm{pH}$, viscosity, extrudability, spreadability, and drug content was found to be light brown,7, 784000 cps, $97.45 \pm 4.1, \quad 25.41, \quad 55.90 \%$ respectively and that's why these batch were selected for the stability study. The results of stability study of the final gel reveal that no changes were noticed in all the tested physicochemical parameter during 3 month in at $40^{\circ} \mathrm{C} \pm 2{ }^{\circ} \mathrm{C} 75 \% \mathrm{RH}$. Comparative microbial assay by well diffusion method shows satisfactory results in $E$ coli bacteria. The methanolic extracts and formulation inhibits the growth of E.coli. Methanolic extracts of 
Amorphophallus paeoniifolius tuber exhibits high quantity of flavonoid like quercetin and they shows antiinflammatory activity as well as the phytoconstituents like phenol, sterols, alkaloids.

\section{CONCLUSION}

Methanol extracts Amorphophallus paeoniifolius tuber showed the presence of flavonoid content and phenolic content. Invitro Anti-Inflammatory activity (HRBC) of Amorphophallu spaeoniifolius extract showed that it may be beneficial for various inflammatory disease. Flavonoid compounds can act on COX pathway as a NSAIDs so Gel of methanolic extract of Amorphophallus paeoniifolius tubers can acts as Anti-Inflammaory gel.

\section{REFERENCES}

[1] Kakrani PH, Kakrani HN, Saluja AK. Evaluation of anti-inflammatory activity of methanolic extract of the aerial parts of Alysicarpus monilifer L.(DC.). Journal of Pharmacy Research. 2011 Oct;4(10):3529-3530.

[2] Lindner J, Lindner C. Pathology of connective tissue. Clinical Hemorheology and Microcirculation. 1982 Jan 1;2(5-6):453-95.

[3] Weston JP.Theresa NV and VeierstedKB. Screening for nonspecific neck shoulder disorders in working female computer users. University of Surrey (United
Kingdom); 2010.BMC Mukoskelatal Disorders 11(79)2-15.

[4] Saeed F. Nonsimultaneous bilateral nonrhegmatogenous retinal detachments presenting as a complication of panuveitis in the setting of idiopathic orbital inflammatory syndrome. OptometryJournal of the American Optometric Association. 2011 Dec 1;82(12):728738.

[5] Singh A, Wadhwa N. A review on multiple potential of aroid: Amorphophallus paeoniifolius. Int $\mathrm{J}$ Pharm Sci Rev Res. 2014;24(1):55-60.

[6] A. Singh, S. Mitra et al. Determination of Antinutritional Changes in Elephant Foot Yam (Amorphophallus paeoniifolius Dennst- Nicolson) Cultivars during Storage. publication at: https://www.researchgate.net/publicatio n/324586262. Chem Sci Rev Lett 2018, 7(25), 19-24.

[7] Karthika G, Das A, Santhy KS. Antioxidant and cytotoxic effects of methanol extracts of Amorphophallus paeoniifolius Ni. Asian Journal of Pharmaceutical and Clinical Research. 2015 Nov 1:106-109.

[8] De S, Dey YN, Ghosh AK. Phytochemical investigation and chromatographic evaluation of the different extracts of tuber of Amorphaphallus paeoniifolius 
(Araceae). Int $\mathrm{J}$ Pharm Biol Res. 2010;1(5):150-157.

[9] Mansour RB, Jilani IB, Bouaziz M, Gargouri B, Elloumi N, Attia H, Ghrabi-Gammar Z, Lassoued S. Phenolic contents and antioxidant activity of ethanolic extract of Capparis spinosa. Cytotechnology. 2016 Jan $1 ; 68(1): 135-142$.

[10] Singleton VL, Orthofer R, LamuelaRaventos RM. Oxidants and antioxidants, Pt A. Methods in enzymology. 1999;299:152-178.

[11]Ribarova F, Atanassova M. Total phenolics and flavonoids in Bulgarian fruits and vegetables. Journal of the university of chemical technology and metallurgy. 2005;40(3):255-260.

[12] Mensor LL, Menezes FS, Leitão GG, Reis AS, Santos TC, Coube CS, Leitão SG. Screening of Brazilian plant extracts for antioxidant activity by the use of DPPH free radical method. Phytotherapy research. 2001 Mar;15(2):127-130.

[13] Saleem TM, Azeem AK, Dilip C, Sankar C, Prasanth NV, Duraisami R. Anti-inflammatory activity of the leaf extacts of Gendarussa vulgaris Nees. Asian Pacific Journal of Tropical Biomedicine. 2011 Apr 1;1(2):147149.

[14] Jyothi D, Koland M. Formulation and evaluation of an herbal anti- inflammatory gel containing Trigonella foenumgreacum seed extract. Int J Pharm Pharm Sci. Int J Pharm Pharm Sci, Vol 8, Issue 1, 4144.

[15]Basha BN, Prakasam K, Goli D. Formulation and evaluation of gel containing fluconazole-antifungal agent. Int J Drug Dev Res. 2011 Oct;3(4):119-27.

[16] Verma A, Singh S, Kaur R, Kumar A, Jain UK. Formulation, optimization and evaluation of clobetasol propionate gel. International Journal of Pharmacy and Pharmaceutical Sciences. 2013;5(4):666-74.

[17]Bhanger MI, Bukhari SB, Memon S. Antioxidative activity of extracts from a Fenugreek seeds (Trigonella foenumgraecum). Pakistan Journal of Analytical \& Environmental Chemistry. 2008 Dec Vol. 9, No. 2 7883

[18]Kumar N., Chakraverty R, Mondal D, Chakraborty P. Phytochemical characterisation and evaluation of the in-vitro antioxidant profile and antibacterial effect of extracts of Amorphophallus paeoniifolius (Dennst.). gjsst. 2019 1(1): 040-047. 